\title{
ANALISIS PENGEMBANGAN INDUSTRI KOMPONEN KAPAL DALAM NEGERI
}

\author{
Analysis of Local Ship Component Industry Development
}

\author{
Taufan Prasetyo ${ }^{1}$, Buana Ma'ruf ${ }^{2}$, Aries Sulisetyono ${ }^{1}$ \\ ${ }^{1}$ Institut Teknologi Sepuluh Nopember, Surabaya \\ ${ }^{2}$ Pusat Teknologi Rekayasa Industri Maritim, BPPT \\ Email: ${ }^{2}$ buana.maruf@bppt.go.id
}

Diterima: 28 September 2016; Direvisi: 21 Nopember 2016; Disetujui: 24 Nopember 2016

\begin{abstract}
Abstrak
Industri komponen kapal memiliki peran yang sangat penting dalam mendukung kemajuan industri galangan kapal dan industri pelayaran nasional. Namun sejauh ini tingkat kandungan dalam negeri sangat rendah yaitu hanya sekitar 30 persen (barang dan jasa). Hal ini disebabkan karena skala ekonomi industri perkapalan nasional belum mampu membuat industri ini berkembang. Adanya program Pemerintah untuk mendorong produksi kapal di dalam negeri dewasa ini menjadi peluang bagi berkembangnya industri komponen kapal lokal, terutama dengan adanya kebijakan standarisasi kapal. Pengembangan industri komponen kapal dalam negeri merupakan salah satu faktor untuk meningkatkan daya saing galangan kapal nasional dengan cepat. Makalah ini menganalisis potensi pengembangan industri komponen kapal dalam negeri berdasarkan faktor-faktor yang berpengaruh menggunakan metode AHP (Analytical Hierarchy Process) sekaligus menganalisis potensi pengembangan industri komponen kapal untuk studi kasus kapal perintis 750 DWT milik pemerintah. Berdasarkan hasil penelitian, didapatkan potensi pengembangan komponen yang paling besar terletak pada kelompok komponen Hull Construction di mana bobot biaya pada kelompok komponen ini terhadap biaya pembangunan kapal adalah yang paling besar. Kelompok komponen Hull Contruction dipilih berdasarkan karakter komponen-komponen yang ada di dalamnya dan memiliki kemungkinan paling besar untuk dikembangkan industrinya di Indonesia melalui metode AHP. Prioritas utama pengembangan pada kelompok komponen Hull Construction terletak pada pengembangan industri baja yang difokuskan untuk komponen material pelat dan profil baja yang di mana bobot biaya pada komponen ini terhadap bobot biaya pembangunan kapal adalah yang terbesar dengan melakukan penguatan di sektor industri hulu hingga hilir memanfaatkan sumber daya lokal.
\end{abstract}

Kata kunci : Komponen Kapal, Daya Saing, AHP, Industri Baja

\section{Abstract}

Ship components industry has a very important role in shipbuilding industry development. But so far, the local content are at low level which about 30 percent. It because the economic's scale of national shipbuilding industry has not been able to support this industry's development. The Government's program to support the local ship production is an opportunity for the development of local ship parts industry, especially with the ship standardization policy. Local ship component industry development is one of the most affected factors which can improve the competitiveness of the national shipbuilding. This paper is analyzing both the potential of ship components industry development based on the most affected factors using AHP (Analytical Hierarchy Process) method and the ship component industries development with case study of 750 DWT Pioneer Vessel. Based on the results of research, Hull Construction group of components has the most potential to develop which has the biggest cost weight percentage to total ship production cost. Hull Construction group of components is selected by the result of AHP analysis with considering the characteristics of the components and have the highest possibilities to develop the industries. The main priority of the 
industry development on Hull Construction group of components are focused on steel industry which product steel plate and profile for ship production Steel plate and profile have the highest weight cost percentage of ship's cost production. The development is about strengthening on all sectors (up to downstream) by optimizing local resource.

Keywords: Ship Components, Competitiveness, AHP, Steel Industry

\section{PENDAHULUAN}

Saat ini, industri perkapalan dunia masih dikuasai oleh tiga negara yang disebut Asian Triangle yaitu Cina, Jepang, dan Korea, dengan penguasaan pasar hingga 90 persen dari total jumlah pesanan kapal di seluruh dunia. Sebagai salah satu negara dengan garis pantai terpanjang di dunia, Indonesia seharusnya memiliki potensi untuk bersaing di industri perkapalan dunia. Namun, sejak program pembangunan Caraka Jaya hingga krisis moneter menerpa, utilitas galangan di Indonesia kian menurun dan industri galangan Indonesia semakin sulit bersaing di industri perkapalan dunia. Hal ini justru berbanding terbalik dengan negara tetangga Filipina, Vietnam, dan Singapura yang masuk dalam 20 besar peringkat negara dengan penguasaan pasar terbesar terkait jumlah pesanan kapal.

Terdapat tiga indikator daya saing industri galangan kapal, yaitu terkait kualitas, harga, dan waktu. Berdasarkan penelitian sebelumnya, dikatakan bahwa faktor yang paling berpengaruh terhadap daya saing galangan kapal adalah faktor yang berhubungan dengan komponen-komponen kapal kapal meliputi harga, kualitas, dan ketersediaan barang. Permasalahan utama industri perkapalan dalam negeri adalah sekitar 70 hingga 80 persen dari komponen yang terpasang pada kapal merupakan komponen impor. Dari sisi harga, menggunakan komponen impor tentunya akan lebih mahal dikarenakan barang impor pasti dikenai pajak impor atau bea masuk. Sedangkan dari sisi waktu, proses pemesanan komponen impor membutuhkan waktu sehingga waktu produksi kapal menjadi lebih lama, terutama komponen mesin induk yang membutuhkan waktu hingga 8 bulan sejak pemesanan.

Beberapa cara dilakukan pemerintah untuk mengoptimalkan dan memacu pertumbuhan industri komponen kapal dalam negeri. Salah satunya adalah penerapan Azas Cabotage yang bertujuan memberdayakan industri dalam negeri yang mencakup industri pelayaran, industri galangan kapal, dan industri penunjang perkapalan terutama komponen kapal.
Kemudian pembangunan kapal dalam jumlah besar melalui program tol laut pemerintah yang didukung dengan kebijakan penggunaan produk dalam negeri. Kebijakan ini mewajibkan penggunaan produk dalam negeri untuk barang atau jasa milik pemerintah minimal 40 persen yang dalam hal ini berupa komponen kapal untuk kapal milik pemerintah. Selain itu, program standarisasi tipe dan ukuran kapal juga dicanangkan pemerintah untuk menciptakan skala ekonomi yang baik sehingga mampu mendorong pertumbuhan industri penunjang perkapalan khususnya industri komponen kapal dalam negeri.

\section{KAJIAN PUSTAKA}

\section{Kondisi Industri Perkapalan Dalam Negeri}

Secara geografis, Indonesia sebagai negara kepulauan terbesar di dunia terletak di posisi yang sangat strategis karena berada di antara dua samudera yaitu Samudera India dan Samudera Pasifik yang merupakan jalur perdagangan antar negara AsiaPasifik di mana sekitar 70 persen perdagangan dunia berlangsung di sana. Dengan garis pantai terpanjang di dunia Indonesia seharusnya memiliki potensi yang sangat besar untuk masuk dalam persaingan industri perkapalan dunia khususnya industri galangan kapal. Namun pada kenyataannya, industri perkapalan di Indonesia masih sulit bersaing di pasar internasional.

Industri galangan kapal adalah industri yang padat karya, padat modal, dan padat teknologi (Ma'ruf, 2010). Terdapat beberapa permasalahan terkait industri galangan kapal di Indonesia menurut BKI (Biro Klasifikasi Indonesia, 2015), antara lain:

- Kapasitas dan produktivitas galangan nasional masih rendah.

- Fasilitas dan peralatan di banyak galangan kapal sudah tua.

- Harga kapal buatan galangan dalam negeri relatif lebih mahal 10 hingga 30 persen.

- Lemahnya dukungan perbankan local.

- Sekitar 70 hingga 80 persen komponen dan material kapal masih harus diimpor. 
Sedangkan menurut Kementerian Perindustrian, penyebab utama rendahnya daya saing galangan kapal dalam negeri mengacu pada dua indikator daya saing antara lain (Kemenperin, 2015):

\section{Harga}

- Tingginya ketergantungan terhadap material dan komponen impor (mencapai 70 persen dari total biaya pembangunan kapal).

- Pengenaan bea masuk terhadap barang impor sekitar 5 hingga 12 persen.

- Pengenaan PPN sebesar 10 persen untuk penyerahan kapal.

- Bunga bank yang tinggi mencapai 12 persen per tahun.

- Harga sewa lahan yang semakin tinggi di area pelabuhan.

2. Waktu

- Lamanya waktu tunggu kedatangan komponen impor.

- Sebagian besar fasilitas galangan yang masih konvensional dan sudah tua.

- Rendahnya sistem manajemen produksi.

Berdasarkan penjelasan dari pihak BKI maupun pihak Kementerian Perindustrian, dapat dilihat bahwa faktor penggunaan komponen dan material impor merupakan faktor yang paling sering disebut. Hal ini tidak lepas dari fungsi dan peranan ketersediaan komponen dan material terhadap tingkat daya saing industri galangan kapal. Berdasarkan penelitian sebelumnya, faktor ketersediaan bahan baku (material dan komponen) merupakan faktor yang paling berpengaruh terhadap tingkat daya saing industri galangan kapal baik bisnis bangunan baru maupun reparasi.

Tabel 1. Faktor eksternal untuk variabel produk pada bisnis bangunan baru (atas) dan reparasi (bawah) (Ma'ruf, 2010)

\begin{tabular}{ll} 
Variabel Faktor Fksternal & Bobot \\
\hline Faktor 1: Produk Anlara & \\
\hline E.01 Mutu material & 0.19 \\
E.02 Harga malerial & 0.18 \\
E.03 Penguasaan pemasok & 0.17 \\
\hline Variabel Faklor Eksternal & Bubol \\
\hline Faklor I: Produk Antara & \\
\hline F.01 Harga malerial & 0.22 \\
E.02 Mutu material & 0.21 \\
E.03 Mutu tenaga subkontraktor & 0.20 \\
\hline
\end{tabular}

Angka pada bobot menunjukkan besarnya pengaruh material kapal dalam menciptakan daya saing galangan yang meliputi mutu, harga, dan penguasaan pemasok. Untuk bisnis bangunan baru, faktor-faktor tersebut sangat berpengaruh hingga 54 persen total sedangkan untuk bisnis reparasi kapal mencapai 63 persen.

Pentingnya faktor ketersediaan bahan baku komponen dan material membuat pemerintah melakukan berbagai upaya untuk mendorong pertumbuhan dan perkembangan industri komponen dan material kapal di dalam negeri melalui sejumlah program dan kebijakan. Penerapan asas cabotage yang digagas pemerintah sebelumnya dinilai hanya menguntungkan industri pelayaran tidak termasuk industri galangan kapal dan industri penunjang perkapalan dalam negeri. Oleh karena itu, sejumlah kebijakan pun dibuat dalam rangka memaksimalkan potensi industri perkapalan khususnya industri galangan dan komponen kapal dalam negeri antara lain:

- Undang-undang No.17/2008, tentang Pelayaran, khususnya pasal 56 dan 57.

- Peraturan Menteri Perindustrian No.124/2009, tentang Roadmap Industri Perkapalan Nasional.

- INPRES No.2/2009 tentang Penggunaan Produk Dalam Negeri Dalam Pengadaan Barang/Jasa Pemerintah (P3DN).

- Peraturan Presiden No.70/2012, tentang Pengadaan Barang/Jasa Pemerintah.

- Peraturan Menteri Perindustrian No.15/2011, tentang Pedoman Penggunaan Produk Dalam Negeri Dalam Pengadaan Barang/Jasa Pemerintah

- Peraturan Menteri Perindustrian No.16/2011, tentang Ketentuan dan Tata Cara Perhitungan Tingkat Komponen Dalam Negeri

- Peraturan Menteri Keuangan No.261/2010 tentang BMDTP (Bea Masuk Ditanggung Pemerintah) atas atas impor barang dan bahan untuk memproduksi barang dan/atau jasa guna kepentingan umum dan peningkatan daya saing industri sektor tertentu

- Peraturan Pemerintah (PP) Nomor 69/2015. Tentang Impor dan Penyerahan Alat Angkutan Tertentu dan Penyerahan Jasa Kena Pajak Terkait Alat Angkutan Tertentu Yang Tidak Dipungut Pajak Pertambahan Nilai (PPN)

Sejumlah kebijakan yang dibuat pemerintah juga diterapkan pada proyek pembangunan kapal jangka panjang secara besar-besaran melalui program tol laut. Program ini berlangsung selama lima tahun mulai dari 2014 hingga 2019 dengan rincian pembangunan dapat dilihat pada Tabel 2 . 
Tabel 2. Rincian pembangunan kapal untuk infrastruktur tol laut (BAPPENAS, 2014)

\begin{tabular}{|c|c|c|c|c|c|c|c|c|}
\hline \multirow{4}{*}{ таник } & \multicolumn{4}{|c|}{ CONTAINER } & \multirow{3}{*}{\multicolumn{2}{|c|}{ 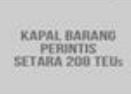 }} & \multirow{3}{*}{\multicolumn{2}{|c|}{$\begin{array}{l}\text { KAPAL } \\
\text { PEIAYARAN } \\
\text { RAKYAT }\end{array}$}} \\
\hline & \multirow{2}{*}{\multicolumn{2}{|c|}{$\frac{15.000 \mathrm{DWT}}{1.000 \mathrm{TEH}}$}} & \multirow{2}{*}{\multicolumn{2}{|c|}{$\frac{40.000 \mathrm{owT}}{3.000 \mathrm{rEvs}}$}} & & & & \\
\hline & & & & & & & & \\
\hline & $\log$ & $\begin{array}{l}\text { Mowe } \\
\text { Ripen }\end{array}$ & rescos & Ning & $\frac{1}{x+2 n}$ & $\begin{array}{l}\text { Mor } \\
\text { Alsen }\end{array}$ & thent & Mois \\
\hline 2015 & 10 & 20000 & 0 & 0 & B & 1280 & 50 & 2.500 \\
\hline 2016 & 10 & 2.500 & 0 & 0 & 7 & 1120 & 100 & 5000 \\
\hline 2017 & 9 & 2250 & 12 & 5.400 & 4 & 640 & 120 & 6.000 \\
\hline 2018 & 9 & 2.500 & 12 & 5.400 & 4 & 540 & 130 & 6.500 \\
\hline 2019 & 8 & 2000 & 13 & 5.850 & 3 & 480 & 100 & 5000 \\
\hline TOTaL & 46 & 11500 & 37 & 16.650 & 26 & 4160 & 500 & 25000 \\
\hline
\end{tabular}

Kemungkinan program ini akan terus dilanjutkan selepas tahun 2019 atau masa pemerintahan yang baru mengingat banyaknya jumlah kebutuhan kapal yang harus dibangun dikarenakan jumlah kapal bekas hasil impor untuk armada kapal nasional masih banyak dan pembatasan usia kapal bekas impor dari usia 20 tahun menjadi 15 tahun. Dengan adanya pembangunan dalam jumlah besar ini, diharapkan mampu mendorong perkembangan dan pertumbuhan industri penunjang perkapalan khususnya industri komponen kapal dalam negeri.

Selain program tol laut, pemerintah juga mulai mencanangkan program standarisasi tipe dan ukuran kapal. Program ini bertujuan untuk mempercepat proses pembangunan kapal pada tahap desain dengan mengurangi jumlah variasi tipe dan ukuran kapal sehingga menghasilkan kesamaan desain, kesamaan sistem, kesamaan spesifikasi, dan kesamaan komponen. Kapal yang dihasilkan pada program ini cenderung memiliki kesamaan atau sister ship. Standarisasi kapal ini juga akan memberi kemudahan dan nilai ekonomis di dalam pengoperasian, pemeliharaan, dan perbaikannya, serta mendorong perkembangan industri komponen lokal dengan skala ekonomi yang tinggi.

\section{Komponen Kapal}

Secara umum, komponen pada kapal dibagi menjadi tujuh kelompok menurut BKI antara lain:

1. Material Pelat dan Profil (Hull Construction)

2. Perlengkapan Lambung (Hull Outfitting)

3. Peralatan Permesinan (Machinery Outfitting)

4. Peralatan Kelistrikan (Electrical Outfitting)

5. Peralatan Navigasi dan Komunikasi

6. Peralatan Keselamatan

7. Perlengkapan Akomodasi
Tiap-tiap kelompok komponen terdiri dari berbagai macam jenis komponen kapal dengan kesamaan fungsi dan berbagai macam karakteristik. Menurut BPPT, terdapat setidaknya delapan karakteristik produk komponen kapal, antara lain:

1. Umum digunakan di banyak tipe kapal

2. Volume kebutuhannya besar

3. Bahan baku tersedia di dalam negeri

4. Teknologinya bisa dikuasai

5. Mudah disertifikasi

6. Sudah dan pernah diproduksi lokal

7. Memiliki potensi ekspor yang cukup besar

8. Bernilai tinggi

Karakter-karakter tersebut yang menjadi pertimbangan dasar dalam pengembangan industri komponen dalam negeri

\section{Kondisi dan Kesiapan Industri Komponen Kapal Dalam Negeri}

Industri komponen kapal dalam negeri sendiri sebenarnya juga masih belum begitu berkembang. Hal ini ditandai dengan masih banyaknya perusahaan galangan kapal yang mengimpor komponen-komponen kapal dari luar negeri (dikatakan sebelumnya bahwa kandungan impor mencapai 80 persen). Di sisi lain, menurut Kementerian Perindustrian setidaknya terdapat lebih dari 70 perusahaan dalam negeri yang memproduksi komponen kapal dengan rincian sebagai berikut:

1. Main Switchboard dan Panel Distribusi (10 Perusahaan)

2. Material Pelat (2 Perusahaan)

3. Profil (7 Perusahaan)

4. Propeller (3 Perusahaan)

5. Casting Materials (1 Perusahaan)

6. Welding Electroda/Kawat Las (1 Perusahaan)

7. Deck Macinery, Crane, Windlass, Winchess, Deck Equipment, Pressure Vessel Boiler (5 Perusahaan)

8. Rantai Jangkar (1 Perusahaan)

9. Pipa Baja (2 Perusahaan)

10. Mur dan Baut (2 Perusahaan)

11. Radio dan Peralatan Navigasi (6 Perusahaan)

12. Cathodic Protection/Anode (5 Perusahaan)

13. Marine Paint (8 Perusahaan)

14. Generator Set (6 Perusahaan)

15. Pompa (4 Perusahaan)

16. Fire Fighting (3 Perusahaan)

17. Life Boat (3 Perusahaan) 


\section{Kabel (6 Perusahaan)}

Dari daftar perusahaan-perusahaan komponen tersebut, hanya komponen mesin induk yang belum diproduksi di dalam negeri atau dengan kata lain, industrinya masih belum ada.

Dari segi kesiapan industri, terdapat beberapa faktor yang mendukung kesiapan industri komponen kapal dalam negeri dalam rangka pengembangan industri komponen antara lain:

\section{- Ketersediaan Sumberdaya}

Menurut Kementerian Perindustrian, Indonesia memiliki potensi cadangan SDA pasir besi yang cukup melimpah untuk pembuatan baja sebagai bahan baku utama pembentuk kapal dan potensi bahan baku karet. Sedangkan dari sisi SDM, upah pekerja di Indonesia relatif lebih rendah dibanding negara Asia lainnya.

- Keberadaan Industri

Selain komponen mesin induk, industri komponen kapal dalam negeri sudah cukup banyak. Selain itu, industri komponen untuk otomotif yang cukup banyak juga berpeluang untuk memasuki pasar industri perkapalan.

\section{- Kebijakan Pemerintah}

Sudah banyak kebijakan pemerintah yang dibuat untuk mendukung perkembangan dan pertumbuhan industri komponen kapal dalam negeri.

\section{- Skala Ekonomi}

Pembangunan kapal dalam jumlah besar melalui program tol laut dan adanya program standarisasi tipe dan ukuran kapal akan menciptakan skala ekonomi yang baik sehingga memungkinkan komponen kapal bisa diproduksi secara massal dan dalam jumlah yang besar.

\section{METODOLOGI}

Penelitian ini menggunakan pendekatan AHP (Analytical Hierarchy Process) untuk menghitung tingkat kepentingan tiap-tiap karakter komponen kapal sebagai dasar pertimbangan prioritas pengembangan industri komponen kapal didukung dengan data hasil studi literatur dan observasi lapangan. Dari hasil studi literatur dan observasi disusun suatu struktur AHP dengan 4 tingkatan Hirarki yang terdiri dari:

1. Tujuan (tingkat teratas): Pengembangan Industri Komponen Kapal Dalam Negeri.

2. Pengambil Keputusan : Pemerintah, Lembaga Sertifikasi, Industri Galangan, Industri Komponen Kapal.
3. Kriteria : - Kebijakan Perbankan, Kebijakan Keuangan, Kebijakan Industri, Pemilik Proyek (Pemerintah).

- Sertifikasi TKDN, Sertifikasi komponen dan pabrik (Lembaga Sertifikasi).

- Bisnis Bangunan Baru, Bisnis Reparasi (Industri Galangan).

- Skala Kecil, Menengah, Besar (Industri Komponen Kapal).

4. Alternatif : Karakteristik produk komponen kapal Kemudian dibuat kuisioner berdasarkan struktur AHP dengan responden yang mewakili pihak Pemerintah, Lembaga Sertifikasi, Galangan, dan Industri Komponen.

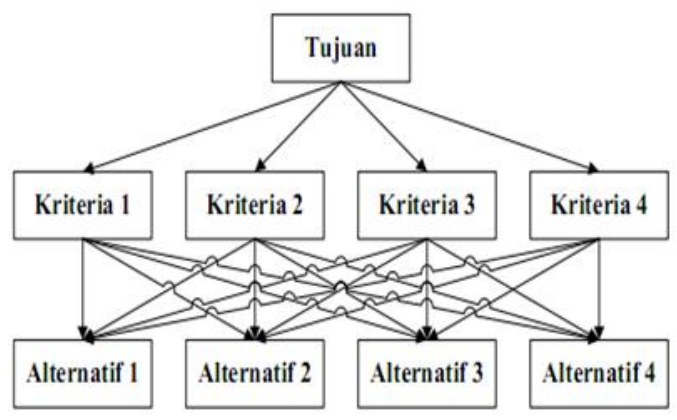

Gambar 1. Contoh struktur AHP

Dari hasil analisis AHP, dihasilkan suatu bobot tingkat kepentingan dari tiap-tiap karakteristik produk komponen kapal. Kemudian tingkat kesesuaian karakter komponen terhadap kelompok komponen dihitung menggunakan pembobotan karakter produk komponen sehingga prioritas pengembangan industri komponen kapal bisa ditentukan.

Selain itu, analisis potensi pengembangan industri komponen yang paling memungkinkan dikembangkan di dalam negeri dengan mempertimbangkan kesiapan industrinya meliputi ketersediaan sumberdaya (SDM maupun bahan baku), keberadaan industri, kebijakan pemerintah, dan skala ekonomi yang bisa dicapai dengan pengembangan industri komponen tersebut.

\section{HASIL DAN PEMBAHASAN}

\section{Analisis AHP}

Dihitung nilai rata-rata geomean hasil pengisian kuisioner AHP pada tiap-tiap tingkatan hirarki. Hasil perhitungan tersebut kemudian direkap dalam sebuah 
matriks AHP dengan susunan sebagai berikut,

$$
\left|\begin{array}{cccc}
1 & \alpha_{i 2} & \cdots \ldots & \alpha_{l n} \\
1 / \alpha_{l 2} & 1 & \cdots \cdots & \alpha_{2 n} \\
\vdots & \vdots & \ddots & \vdots \\
1 / \alpha_{l n} & 1 / \alpha_{2 n} & \cdots \cdots & 1
\end{array}\right|
$$

seperti yang ditunjukkan pada Tabel 3 .

Tabel 3. Matriks untuk pengambil keputusan

\begin{tabular}{|c|c|c|c|c|}
\hline Matriks & PEMERINTAH & L. SERTIFIKASI & GALANGAN & $\begin{array}{c}\text { IND. } \\
\text { KOMPONEN }\end{array}$ \\
\hline PEMERINTAH & 1 & 1.50 & 2.59 & 1.32 \\
\hline L. SERTIFIKASI & 0.67 & 1 & 2.94 & 1 \\
\hline GALANGAN & 0.39 & 0.34 & 1 & 0.67 \\
\hline IND. KOMPONEN & 0.76 & 1 & 1.50 & 1 \\
\hline Jumlah & 2.82 & 3.84 & 8.03 & 3.99 \\
\hline
\end{tabular}

Kemudian matriks dinormalisasi dengan membagi setiap nilai pada kolom matriks dengan hasil penjumlahan masing-masing kolom seperti yang ditunjukkan pada Tabel 4.

Tabel 4. Hasil normalisasi matriks

\begin{tabular}{|l|rrrr|}
\hline PEMERINTAH & 0.36 & 0.39 & 0.32 & 0.33 \\
L. SERTIFIKASI & 0.24 & 0.26 & 0.37 & 0.25 \\
GALANGAN & 0.14 & 0.09 & 0.13 & 0.17 \\
IND. KOMPONEN & 0.27 & 0.26 & 0.19 & 0.25 \\
\hline \multicolumn{1}{|c|}{ Jumlah } & 1 & 1 & 1 & 1 \\
\hline
\end{tabular}

Nilai rata-rata tiap baris matriks adalah nilai eigenvector yang menunjukkan bobot tingkat kepentingan masing-masing variabel.

Tabel 5. Nilai eigenvector untuk pengambil keputusan

\begin{tabular}{|l|c|}
\hline \multicolumn{1}{|c|}{ Pengambil keputusan } & eigenvector \\
\hline PEMERINTAH & 0.35 \\
L. SERTIFIKASI & 0.28 \\
GALANGAN & 0.13 \\
IND. KOMPONEN & 0.24 \\
\hline \multicolumn{1}{|c|}{ TOTAL } & 1 \\
\hline
\end{tabular}

Perhitungan AHP dibatasi dengan nilai $C R$ (Consistency Ratio) untuk mengukur keseluruhan konsistensi penilaian yang tidak boleh lebih dari 0,1 yang artinya tingkat keakuratan data di atas 90 persen. Perhitungan dilanjutkan pada tingkatan hirarki selanjutnya atau dibawahnya hingga tingkatan paling akhir hirarki dengan variabel alternatif.
Tabel 6. Hasil pembobotan untuk alternatif karakter produk yang akan dikembangkan

\begin{tabular}{|l|c|}
\hline \multicolumn{1}{|c|}{ Prioritas pengembangan } & Bobot \\
\hline 1. Teknologi produksinya dapat dikuasai & 0.186 \\
\hline 2. Umum digunakan di semua tipe kapal & 0.167 \\
\hline 3. Bahan baku tersedia di dalam negeri & 0.135 \\
\hline 4. Mudah disertifikasi & 0.133 \\
\hline 5. Volume kebutuhan besar & 0.122 \\
\hline 6. Sudah/pernah diproduksi lokal & 0.095 \\
\hline 7. Memiliki potensi ekspor yang cukup besar & 0.085 \\
\hline 8. Bernilai tinggi & 0.078 \\
\hline \multicolumn{2}{|c|}{ TOTAL } \\
\hline
\end{tabular}

Hasil pembobotan pada tabel 6, digunakan untuk menghitung nilai tingkat kesesuaian terhadap industri pada masing-masing kelompok komponen seperti contoh yang ditunjukkan pada Tabel 7 .

Tabel 7. Hasil rata-rata tingkat kesesuaian untuk kelompok komponen hull contruction

\begin{tabular}{|c|c|c|c|c|}
\hline \multirow{2}{*}{ No } & \multirow{2}{*}{ Prioritus pergembangan } & \multicolumn{2}{|c|}{$\begin{array}{l}\text { Aall Constriction Material Pelat } \\
\text { dan Profil }\end{array}$} & \multirow{2}{*}{$\begin{array}{l}\text { Nilai Avhir } \\
(\mathrm{b} / 5 \mathrm{x} \text { a })\end{array}$} \\
\hline & & $\begin{array}{l}\text { Boboc } \\
\text { (a) }\end{array}$ & $\begin{array}{l}\text { Skor rata-rata } \\
\text { (b) }\end{array}$ & \\
\hline 1 & Teknologi produksinya dapat dikuasai & 0.186 & 4.75 & 0.177 \\
\hline 2 & Uimum digunakan di semua tipe kapal & 0.167 & 4.5 & 0.150 \\
\hline 3 & Bahan baku tersedia di dalam negeri & 0.135 & 4.75 & 0.128 \\
\hline 4 & Mudah disertifikasi & 0.133 & 4.5 & 0.120 \\
\hline 5 & \begin{tabular}{|l} 
Volume kebutuhan besar \\
\end{tabular} & 0.122 & 5 & 0.122 \\
\hline 6 & Sudahpernah diproduksi local & 0.095 & 4.75 & 0.090 \\
\hline 7 & $\begin{array}{l}\text { Memiliki potensi dkspor yang cukup } \\
\text { besar }\end{array}$ & 0.085 & 4.5 & 0.077 \\
\hline 8 & Bemilai tinggi & 0.078 & 4 & 0.062 \\
\hline & Total & 1 & & 0.926 \\
\hline
\end{tabular}

Dari hasil nilai akhir yang didapat dari penilaian terhadap tingkat kesesuaian industri pada seluruh kelompok komponen kapal, didapat urutan prioritas pengembangan kelompok komponen kapal pada

Tabel 8. Urutan prioritas pengembangan kelompok komponen kapal

\begin{tabular}{|c|l|c|}
\hline No & \multicolumn{1}{|c|}{ Komponen } & Skor \\
\hline 1 & Hull Construction/Material Pelat dan Profil & 0.926 \\
\hline 2 & Perlengkapan Akomodasi dan Perlengkapan Lainnya & 0.767 \\
\hline 3 & Peralatan Keselamatan & 0.764 \\
\hline 4 & Electrical Outfitting/Peralatan Kelistrikan & 0.695 \\
\hline 5 & Hull Outfitting/Perlengkapan Lambung & 0.652 \\
\hline 6 & Peralatan Navigasi dan Komunikasi & 0.589 \\
\hline 7 & Machinery Outfitting/Peralatan Permesinan & 0.525 \\
\hline
\end{tabular}

Hasil analisis menunjukkan bahwa tingkat prioritas tertinggi adalah pada pengembangan komponen-komponen yang ada pada kelompok komponen Hull Construction. Pada kelompok komponen ini didominasi oleh komponen atau material pelat dan profil baja. 


\section{Analisis Potensi Pengembangan Industri}

Berikut adalah bobot biaya pada masing-masing kelompok komponen kapal perintis 750 DWT terhadap biaya total pembangunan kapal.

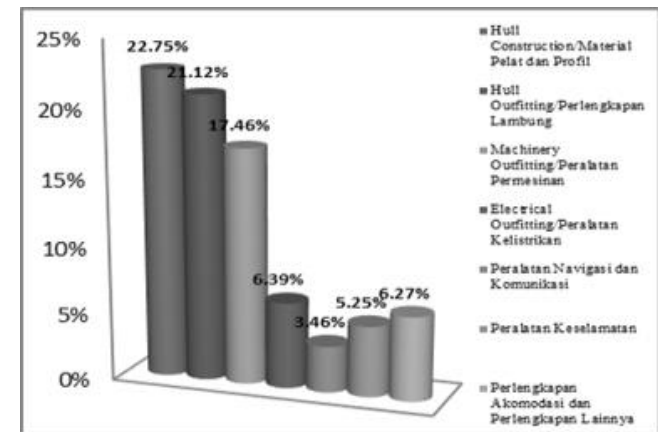

Gambar 2. Bobot biaya tiap-tiap kelompok komponen pada pembangunan Kapal Perintis 750 DWT

Pada gambar di atas, dapat dilihat bahwa bobot biaya terbesar ada pada kelompok komponen Hull Construction. Kelompok komponen ini didominasi oleh material pelat dan profil baja. Seperti yang diketahui bahwa sebagian besar badan kapal terbuat material baja. Tidak hanya pelat dan profil, banyak material lain yang terbuat dari baja seperti jangkar, rantai jangkar, dan lain-lain.

Pada kelompok komponen Hull Construction, pengembangan industri pelat dan profil baja dipilih berdasarkan karakter produk yang volume kebutuhannya besar dan bisa diproduksi secara massal. Volume kebutuhan yang besar mengacu pada bobot biaya kelompok komponen Hull Construction merupakan yang terbesar dan didominasi oleh material pelat dan profil baja. Lebih jauh lagi, industri baja merupakan industri yang sangat strategis karena tidak hanya industri perkapalan saja namun juga mencakup hampir keseluruhan bidang industri mulai dari penyedian infrastruktur (gedung, jalan, jembatan, jaringan listrik dan telekomunikasi), produksi barang modal (mesin pabrik dan material pendukung serta suku cadangnya), alat transportasi (kapal laut, kereta api beserta relnya dan otomotif), hingga persenjataan (Kemenperin, 2014). Pengembangan industri baja pada kelompok komponen Hull Construction tidak hanya akan berimbas pada industri komponen pelat dan profil baja, namun juga pada komponen lain yang berbahan baku material besi dan baja seperti contoh jangkar, rantai jangkar, pintu kedap, jendela, dan lain sebagainya. Oleh karena itu, tingkat daya saing galangan nasional akan sangat dipengaruhi oleh harga bahan baku besi dan baja

Seperti yang diketahui bahwa tingkat daya saing industri galangan dalam negeri masih rendah. Sejak berakhirnya program pembangunan Caraka Jaya di tahun 1998, utilitas galangan di Indonesia terus mengalami penurunan. Oleh karena itu, pemeritah saat ini berusaha untuk membenahi sektor industri perkapalan dimulai dengan adanya program pembangunan kapal untuk tol laut hingga pengembangan di sektor industri komponen kapal. Pengembangan dilakukan untuk mengurangi keergantungan terhadap produk impor yang salah satunya adalah material pelat dan profil baja. Meskipun pabrik pelat dan profil baja di Indonesia sudah banyak, namun pada kenyataannya bahan baku yang digunakan masih impor. Dengan ketersediaan sumberdaya alam pasir besi yang cukup melimpah di Indonesia sekitar 5110 juta ton (Kemenperin, 2014), tentunya peluang untuk memaksimalkan potensi bahan baku lokal masih sangat terbuka.

Saat ini ada beberapa perusahaan yang melakukan penambangan pasir besi, salah satunya adalah PT.Yasindo Abdi Putra yang berlokasi di Tasikmalaya, Jawa Barat dengan kapasitas produksi mampu mencapai 3000 ton pasir besi per hari, Sedangkan perusahaan yang melakukan pengolahan bijih besi menjadi besi spons (sponge iron) hanya terdapat dua buah perusahaan yaitu PT.Meratus Jaya Iron \& Steel dan PT.Delta Prima Steel dengan kapasitas produksi masing-masing sebesar 315 ribu ton dan 100 ribu ton (Kemenperin, 2014). Kelompok industri hulu memproduksi slab dan billet sebagai hasil pengolahan dari hasil tambang pasir besi. Awalnya Indonesia hanya mempunyai satu perusahaan yang memproduksi slab dan billet yaitu PT. Krakatau Steel, di Cilegon, Banten. Belakangan karena adanya masalah PT. Krakatau Steel tidak lagi memproduksi slab dan billet. Untuk memenuhi kebutuhan pabriknya memproduksi produk hilir baja, maka PT. Krakatau Steel mengimpor slab dan billet. Perusahaan dalam negeri lainnya yang memproduksi produk hilir baja, juga mengimpor slab sebagai bahan bakunya. Dalam beberapa tahun terakhir PT.Krakatau Steel bekerja sama dengan Posco Korea Selatan membangun pabrik baja di Banten Indonesia dengan nama PT. Krakatau Posco. Perusahaan ini mengimpor material selanjutnya diproses sebagai bahan baku untuk memproduksi memproduksi slab dan billet (Kemenperin, 2014). 
Sedangkan untuk industri antara, memproduksi produk baja kasar (crude steel) dan baja semi finished product dari bahan baku slab dan billet yang diproduksi industri hulu. Produk dari industri antara akan diproses menjadi barang jadi atau pelat siap pakai di industri hilir.

Pengembangan perlu dilakukan di sektor industri hulu terutama dalam hal pengolahan bahan baku mentah (pasir besi, biji besi) menjadi bahan baku siap olah (slab, billet, dan lain-lain) melalui modernisasi teknologi pengolahan. Pengembangan ini tentunya juga sudah dibarengi dengan program pembangunan kapal pemerintah secara massal dalam jangka waktu yang cukup panjang melalui program tol laut dan program standarisasi kapal. Program-program ini dibuat dengan tujuan untuk menciptakan skala ekonomi yang baik untuk industri komponen kapal dengan cara meningkatkan jumlah kebutuhan komponen kapal dan menciptakan produk yang berpeluang untuk diproduksi secara massal

\section{KESIMPULAN}

Berdasarkan hasil analisis, diambil kesimpulan bahwa komponen kapal yang saat ini perlu dan paling memungkinkan untuk dikembangkan berdasarkan faktor kesiapan industrinya adalah material pelat dan profil baja. Pelat dan profil merupakan material utama pembentuk kapal dan memiliki bobot biaya komponen terbesar terhadap biaya total pembangunan kapal. Oleh karena itu, harga material pelat dan profil sangat berpengaruh terhadap harga kapal. Disamping itu, di Indonesia sendiri sudah terdapat banyak pabrik yang memproduksi pelat dan profil untuk kebutuhan kapal namun belum cukup berkembang karena bahan baku yang digunakan masih impor.

Pengembangan yang perlu dilakukan adalah pengembangan di sektor industri hulu terkait pengolahan bahan baku. Hal ini dikarenakan potensi sumberdaya alam pasir besi di Indonesia masih sangat melimpah yaitu sekitar 5110 juta ton. Pengembangan di sektor pengolahan bahan baku tidak hanya akan memaksimalkan potensi sumberdaya lokal namun juga mampu menekan biaya produksi yang sebelumnya memakai bahan baku impor sehingga didapatkan harga dan kualitas yang mampu bersaing di pasar internasional.

Pengembangan industri baja terutama di sektor industri hulu tidak hanya akan berpengaruh pada industri pelat dan profil baja, namun juga industri lain yang memproduksi komponen kapal lain yang juga terbuat dari besi dan baja. Dan sebagai salah satu industri strategis, pengembangan industri baja tentunya juga akan berdampak pada industri lain yang bergerak di bidang infrastruktur (gedung, jalan, jembatan, jaringan listrik dan telekomunikasi), produksi barang modal (mesin pabrik dan material pendukung serta suku cadangnya), hingga persenjataan.

\section{DAFTAR PUSTAKA}

Asosiasi Industri Komponen Kapal Indonesia. (2015). Forum Group Discussion. Mendukung Program Pemerintah di Bidang Industri Perkapalan. Surabaya.

Biro Klasifikasi Indonesia. (2015). Peran BKI dalam Sertifikasi dan Standarisasi Industri Berbasis Kemaritiman. Jakarta, Kementerian BUMN.

BPPT Bidang Teknologi Industri Rancang Bangun dan Rekayasa. (2015). Kajian Komponen Industri Perkapalan. Konsinyering Kegiatan Inovasi dan Layanan Teknologi Industri Perkapalan. Surabaya, Badan Pengkajian dan Penerapan Teknologi.

IUBTT, D. (2012). Kebijakan Peningkatan Penggunaan Produk Dalam Negeri. Jakarta, Kementerian Perindustrian.

Kemenperin. (2015). Peran Kementerian Perindustrian di Dalam Pengembangan Industri Kapal dan Komponen Dalam Negeri. FGD standarisasi Armada Kapal Domestik untuk Efisiensi Proses Produksi dan Operasional Kapal. Surabaya, PPT Perkapalan 2015 - BPPT.

Kemenperin. (2014). Profil Industri Baja.

Ma'ruf, B. (2010). Analisis Daya Saing Industri Galangan Kapal Nasional Dengan Menggunakan Model Yardstrat. Prosiding Seminar Nasional Manajemen Teknologi XI, Program Studi MMTITS.

Ma'ruf, B. (2014). Standarisasi Tipe dan Ukuran Kapal Untuk Daya Saing Berkesinambungan Bagi Industri Kapal Nasional. Pertemuan dan Presentasi Ilmiah Standarisasi.

Saaty, T. L. (2008). Decision Making With The Analytic Hierarchy Process. (Vol. 1). Pittsburgh, Int. J. Services Sciences. 